\title{
The effect of tourism on gender equality in the labour market: Helpmate or hindrance?
}

\author{
Mahalia Jackman
}

December, 2020

\begin{abstract}
This is a pre-published draft. A revised version of this paper has been published in Women's Studies International Forum (https://www.sciencedirect.com/science/article/pii/S0277539521001175) Please cite the published version.
\end{abstract}

\begin{abstract}
This paper analyses the relationship between tourism and gender equality. Specifically, this study estimates the effects of tourism on gender equality in the labour market using a panel dataset consisting of 143 countries from 2006 to 2017. I find evidence of a positive relationship between tourism and gender equality in the labour market. However, the impact of tourism is not uniform across the sample. For instance, the results imply that tourism is positively correlated with gender equality in developed countries, has an inverse relationship with gender equality in Sub-Saharan Africa, and has no impact on gender equality in the Middle East and North Africa. The implications of these findings are discussed.
\end{abstract}

Keywords: tourism, gender, gender equality, labour market 


\section{Introduction}

Gender equality is an important human rights issue, one that has captured the attention of key international bodies and governments around the world. Over 185 countries are party to the Convention on the Elimination of All Forms of Discrimination Against Women, an international agreement to end discrimination against women in all forms. The focus on gender equality is not surprising. Gender inequality is currently viewed as an issue that affects society and can prohibit an economy from reaching its full potential. Indeed, there is a burgeoning body of literature linking progress in gender equality to increased employment, improvements in economic efficiency and economic growth (International Labour Organization, 2016; Kolovich, 2018; Maceira, 2017; World Bank, 2012). The 2030 Agenda for Sustainable Development (adopted by the United Nations in 2015) has reaffirmed the importance of gender equality for development (United Nations, 2015). Achieving gender equality and empowering all women and girls is listed as Goal 5 of the 17 Sustainable Development Goals (SDGs), with gender equality and women's economic empowerment listed as integral and a prerequisite for progress across all 17 SDGs.

Recent social and employment trends suggest that there has been significant progress in reducing gender inequality at work and in society (Seguino, 2016; World Economic Forum, 2020). Despite global commitments to gender equality and progress in gender parity over the last few decades, significant gender gaps remain. Women continue to be severely underrepresented in leadership roles. There are still reports of considerable gender gaps in job selection, monetary remuneration, employee development, entrepreneurship and access to property ownership, finance and natural resources (Cuberes et al., 2019; Deere \& León, 2003; International Labour Organization, 2016; Kieran et al., 2015; Morsy, 2020; Seguino, 2016). According to the 2020 World Economic Forum's Global Gender Gap report (World Economic Forum, 2020), the average global gender gap in employment, education, health and politics is 31.4 per cent and, it is unlikely that these gaps will exist close anytime soon. Given the trends observed since 2006, the World Economic Forum estimates it will take 99.5 years to close the global divide between women and men in employment, education, health and politics. The report also suggests that progress towards equality will vary across indicators. The World Economic Forum predicts that progress will be slowest in economic participation and opportunity and that it will take another 257 years to close the economic aspect of the global gender gap. The critical question is: how do we speed up the process? Answering this question would require an understanding of the factors influencing gender inequality. Empirical evidence to date suggests that gender inequality is related to a myriad of factors in a country, chief among which are the level of development, legal framework, macroeconomic policy, trade and religion (Gouda \& Potrafke, 2016; Schnabel, 2016; Seguino, 2011; UNWTO, 2019; Wamboye \& Seguino, 2015; World Economic Forum, 2020). In this paper, I opt to focus on the impact of tourism on gender inequality in the labour market.

Recently, there has been much debate on how tourism can contribute to gender inequality and the empowerment of women. Women make up a majority of workers in the tourism industry worldwide (Baum, 2013). In some countries tourism has almost twice as many women as employers than other industries (International Finance Corporation, 2017). Tourism thus has the potential to boost women's employment and entrepreneurship. At the same time, scholars within tourism argue that tourism is a highly gendered industry (Ferguson, 2011), where gender roles are often (though subtly) reproduced (Genç, 2018). Women in tourism are often concentrated in care jobs and require interpersonal skills, notably housekeeping, spa and 
customer contact related jobs with little representation in physically intensive jobs or key managerial positions (Ramchurjee, 2011; UNWTO, 2019).

Taken together, tourism appears to be a mixed blessing for gender equality in the labour market. This study seeks to provide quantitative estimates of the effects of tourism on gender equality in the labour market. Specifically, the study aims to evaluate whether countries with greater tourism density experience greater or lower gender inequality in their labour market. The premise is that the greater the role of tourism in an economy, the greater the link between tourism and labour market outcomes. To carry out this task, I employ a panel dataset of over 140 countries from 2006 to 2017 . I carry out the analysis using a tourism density indicator (that is, tourist arrivals per head of the population) and a composite index from the World Economic Forum that encompasses three measures of gender gaps in labour market outcomes: the overall participation gap, the remuneration gap and the advancement gap.

The results of this study will provide meaningful insights into how tourism specialisation benefits or challenges gender equality. If there is clear-cut evidence that tourism has a mitigating impact on gender inequality, then the focus of policymakers would be on how to harness tourism's positive effects. However, suppose tourism reinforces or exacerbates existing gender inequalities. In that case, tourism stakeholders will need to make significant changes to their current policy framework to mitigate the sector's adverse effects and ensure that men and women can equally benefit from tourism's opportunities.

In addition to the important policy implications, the study also contributes to the academic literature. Until recently, there was little discussion on gender and tourism employment in mainstream tourism research (Morgan \& Pritchard, 2019; Sinclair, 1997). Figueroa- Domecq et al. (2015) carried out a bibliometric analysis of papers published on gender in tourism from 1985 to 2012. Of the 466 articles reviewed, 13.6 per cent were related to gendered labour. While there has been some rise in research on gender and tourism employment in recent years (Figueroa-Domecq et al., 2017), many of the existing studies are at the micro level for an individual country (Hutchings et al., 2020). There are very few academic papers investigating the inter-country relationships between tourism and gender equality in the labour market. Nassani et al., (2019) and Zhang and Zhang (2020) are among the few studies that take a panel approach to examining the link between gender equality and tourism. Zhang and Zhang (2020) use data on 36 Asian countries to evaluate the association between tourism and a composite gender equality index that captures gender parity in health, employment, politics and education. These authors found that tourism positively impacts gender equality, irrespective of whether the entire sample or sub-samples of Asian countries are used. In contrast, Nassani et al., (2019) find that while tourism decreases women's vulnerability in employment, the impact of tourism on women's employment was mixed and varied depending on whether the authors used tourism receipts, travel item receipts or tourism spending as the tourism indicator. This study thus adds to the literature by carrying out a cross-country analysis of the link between tourism and gender equality in the labour market and deviates from the previously mentioned two studies in keyways. First, the study explicitly focuses on the connection between tourism and gender gaps in labour market indicators. As noted by Baum et al. (2016) "consideration of employment and the tourism workforce is at the heart of the sustainable tourism narrative". Notwithstanding the importance of other dimensions of gender equality, I opt to concentrate on gender gaps in the labour market as tourism's impact on the economic aspect of gender equality is likely to be most acute. Second, the study is global and employs a large heterogeneous sample. The sample used in this paper allows for an investigation of whether tourism has different effects 
in some destination countries due to their specific features. Cultural values and gender role belief systems affect progress towards gender equality and women's empowerment (Akerlof \& Kranton, 2000). By extension, tourism can affect the contribution that tourism can have on gender equality. As these barriers are likely to differ across country groupings, it is plausible to assume that tourism's impact on gender equality may not be homogenous across the sample. In this paper, I investigate the relevance of the tourism sector for gender equality for countries at different stages of development and whether there are region-specific effects.

The rest of this paper is organised as follows. Section 2 presents some stylised facts about tourism and gender equality in the labour market, while Section 3 discusses the data and panel data methods used in the study. Section 4 provides the empirical results, and finally, Section 5 presents some concluding remarks.

\section{Tourism and gender equality in the labour market}

Tourism is arguably one of the most important economic sectors in the world (Peña-Sánchez et al., 2020; Ribeiro et al., 2018). Tourism is a major earner of exchange, with tourism receipts accounting for over 50 per cent of export credits in some countries (Jackman, 2014; Jackman et al., 2011). Thus, shocks to tourism can have detrimental impacts on the external current account. Tourism also accounts for a significant proportion of Gross Domestic Product (GDP) and, as a labour-intensive industry, plays a key role in job creation. Satellite accounting by the World Travel and Tourism Council (WTTC) suggests that in 2019, the tourism sector contributed USD 8.9 trillion or 10.3 per cent of global GDP and supported 330 million jobs (that is, 1 in every 10 jobs) worldwide (WTTC, 2020). But, like many other impetuses for growth and development, tourism has both positive and negative effects. This section provides a brief overview of the opportunities and challenges that tourism presents for women's empowerment and gender equality in the labour market.

Supporters of tourism opine that tourism offers numerous avenues for female economic empowerment and advancement, and by extension, has the potential to be a tool for gender equality. As alluded to earlier, tourism is a labour-intensive industry, and as such, growth in tourism over the last few decades has provided women with various entry points for employment (Gil Arroyo et al., 2019; Rinaldi \& Salerno, 2019). Globally, tourism is a female-dominated sector. The UNWTO reports that women account for 54 per cent of persons employed in tourism globally. In many countries, tourism's female employment rate is above the average rate of other sectors (UNWTO, 2019). This raises the question: why are women more likely to be employed in tourism? Some reports link tourism's high rate of female employment to the sector's prevalence of part-time and work from home options (International Finance Corporation, 2017). In every region of the world, women bear a disproportionate amount of time doing unpaid domestic work and child care relative to men (International Labour Organization, 2018), which reduces their ability to participate in the labour market fully. Gendered expectations may cause women to select jobs with hours that can be readily integrated with their perceived familial responsibilities (Buttrose \& Adams, 2005), among which is tourism-related work. Another possible reason for the large number of women working in tourism could be the sector's emphasis on personable and hospitable skills (International Finance Corporation, 2017), which are often stereotyped as "women's skills" (Bynoe \& Jackman, 2019).

There is also evidence suggesting that tourism brings increased opportunities for women's entrepreneurship Field (Aghazamani \& Hunt, 2017; Pritchard, 2014) due largely to the 
sector's low start-up costs. In many countries, the share of women-led businesses in tourism is higher than that for other sectors (Pastore et al., 2020). For instance, in Latin America, over 50 per cent of tourism businesses are owned by women - more than twice the share found in other sectors (International Finance Corporation, 2017).

Not only does tourism allow women to gain an income, but it could also improve selfconfidence (Moswete \& Lacey, 2015), and even alter gender relations. In their study on women and tourism-based entrepreneurship in Fiji, Movono and Dahles (2017) showed that women's involvement in tourism led to economic, psychological, social and political empowerment. The authors further report that a major consequence of this empowerment is the changing roles of men, which has expanded to include care work that was historically (and almost exclusively) done by women.

At this juncture, it is important to point out that tourism's contribution to female economic empowerment varies across regions. For instance, UNTWO (2019) showed that between 2009 and 2018, the share of women employed in accommodation and food services was 69 per cent in Africa, 67 per cent in the Americas, 53 per cent in Europe, 53 per cent in Asia and the Pacific and 9 per cent in the Middle East. The observed heterogeneity in tourism's contribution to women's work opportunities has been linked to differences in the degree of tourism specialisation and institutional, social and cultural differences across regions (Soria \& Teigeiro, 2019; UNWTO, 2019). The persistence of discriminatory laws, practices, attitudes and gender stereotypes can severely limit women's involvement in tourism employment and, by extension, prevent women from gaining all the benefits of tourism (Gil Arroyo et al., 2019; Mooney, 2018; Uduji et al., 2020; UNWTO, 2019).

Moreover, even if tourism brings a much-desired boost to women's employment, one must bear in mind that gender equality and women's empowerment in the labour market goes beyond the number of women employed. The relation between tourism and gender inequality is related to decent work conditions in tourism. Tourism workers face several decent work challenges, including the high incidence of informal working arrangements, insecure employment contacts, limited progression opportunities, limited workplace autonomy, little social protection and poor working conditions (International Labour Office, 2017; Winchenbach et al., 2019). Research also suggests that there is a wage penalty in tourismrelated employment (Moreno \& Cañada, 2018), where on average, tourism workers receive lower wages than workers in other sectors (Brandt, 2018; Casado-Díaz \& Simon, 2016; LilloBañuls \& Casado-Díaz, 2015; Silva \& Guimarães, 2017). The feminisation of tourism work means that women are more likely to face indecent working conditions, which means that greater tourism dependence could reinforce or even exacerbate gender inequalities in a country.

Existing studies document that, like many other sectors of the economy, employment in tourism is structured along gendered lines, and dominant gender norms are often reproduced (Baum, 2013; Ferguson, 2011; Movono \& Dahles, 2017). Several studies report a marked gender pay gap in tourism (favouring men) that cannot be explained by differences in worker endowment (Guimarães \& Silva, 2016; Kortt et al., 2018; Muñoz-Bullón, 2009; Oliver \& Sard, 2020). UNWTO (2019) showed that the gender pay gap differs across countries, and in 55 out of 95 countries, the gender gap in tourism was smaller than the gender gap recorded for the broader economy. This lends further credit to the previously mentioned notions that socio-cultural factors may contribute to or mitigate the gender inequality in tourism markets. There is also evidence that tourism employment is plagued with horizontal and vertical 
segregation (Hutchings et al., 2020). Baum (2013) suggest that horizontal segregation is evident in tourism work with women and men working in occupations in line with existing gender stereotypes regarding the role of men and women in society. Women are more likely to be employed in jobs that require interpersonal skills and care work, such as flight attendants, cleaners, sales personnel, waitresses and travel agents. At the same time, men are likely to be employed as pilots, gardeners, drivers and construction workers (Rinaldi \& Salerno, 2019). Vertically, women tend to be segregated in low-ranking positions and underrepresented in key managerial positions (Baum, 2013; Carvalho et al., 2019; Hutchings et al., 2020; Santero-Sanchez et al., 2015). Carvalho et al., (2019) suggest that beliefs that women are not fit for management, male homosocial ties and hegemonic masculinity still plague the tourism sector and acts as an impediment to women's career advancement.

Taken together, the evidence to date suggests that tourism is a mixed blessing for gender equality. Although tourism has provided opportunities for female employment and career advancement, the sector is still highly gendered and often reinforces gender inequality. In what follows, I quantitatively assess the impact of tourism on gender gaps in various labour market indicators. The results of this study will thus provide further insights into the extent to which tourism has contributed to achieving gender equality.

\section{Data and method}

Data

The paper uses an unbalanced panel dataset consisting of 143 countries over the period 2006 to 2017. Appendix A provides a list of the countries included in the sample. Data on gender equality in the labour are taken from the World Economic Forum's Global Gender Gap reports. The report provides estimates of national gender gaps in four areas: (1) economic participation and opportunity, (2) educational attainment, (3) health and survival and (4) political empowerment. The World Economic Forum was first published in 2006, and the methodology for estimating the gender gaps has remained stable since conception, providing a basis for robust panel analysis. As alluded to in the introduction, the study is only concerned with gender equality in the labour market, and as such, I only utilised the economic participation and opportunity sub-index.

According to the World Economic Forum (2020), the economic participation and opportunity sub-index is a synthesis of five indicators. It captures three dimensions of gender inequality in the labour market: the participation gap, the remuneration gap and the advancement gap. The participation gap is the difference in female and male participation rates and is specified as the female participation rate as a ratio of the male participation rate. Two indicators capture gaps in remuneration. The first indicator is the ratio of estimated female-to-male earned income. Estimates are based on a method developed by the UNDP (United Nations Development Programme, 2015) that considers a country's national GDP per capita, the shares of men and women in the labour force and their mean nominal wages. The second remuneration gap indicator is qualitative and captures wage equality for similar work. It is derived from the World Economic Forum's Expert Opinion Survey, a questionnaire answered by business leaders in over 140 countries (World Economic Forum, 2020). Finally, the advancement gap is captured by two indicators: the ratio of women to men among legislators, senior officials and managers, and the female to male ratio among technical and professional workers. All indices range from 0 (no equality) to 1 (complete equality). 
Tourism is captured as the international tourist arrivals per capita and is expressed in natural logarithms. Data on inbound international tourists and population size are taken from the World Bank Development Indicators (WDI) database. Outside of tourism, the literature suggests that there are several economic, political and social factors that explain differences in gender equality across countries. The control variables used in the study are economic growth, the fertility rate, government size, restrictions on rights and liberties and irreligiosity.

Including economic growth ensures that the model captures the impact of changes in aggregate demand on the labour market and the resultant changes in the differential between male and female labour outcomes (Wamboye \& Seguino, 2015). Turning to government size, the public sector has been lauded as a model employer, as discrimination against women tends to be smaller than that recorded in the private sector (Stritch \& Villadsen, 2018). This may be related to strict pay schemes and the transparency of government wages, which make unequal pay for equal work less probable (Blau \& Kahn, 2017). As such, the size of the government is included to account for how greater government involvement in the economy influences gender equality. I also include the fertility rate as a regressor, as women are primarily responsible for child care, which limits the time they have available to spend in paid work (Jackman \& Lorde, 2021). This has resulted in a (paid) work-hour gender gap, which reinforces other types of labour market inequalities, such as the gender gap in wages (Meara et al., 2020; Blau \& Kahn, 2017; Weeden et al., 2016). and career advancement (Maume, 1999). The fertility rate thus captures the extent to which child-rearing affects women's labour market outcomes and, by extension, gender equality in the labour market.

Following Anyanwu and Augustine (2013), I include the degree of political and civil rights in the regression as greater freedoms are generally associated with greater respect for women's rights, female empowerment and equity in gender relations. Finally, I include irreligiosity as a control variable as research has shown that though religious institutions are not monolithic, most prominent religions are patriarchal (Klingorová \& Havlíček, 2015). Seguino (2011) found that religion perpetuates norms that promote traditional gender role ideologies and practices and that these beliefs, in turn, hurt gender equality in labour markets, household resource allocation, and government spending. Similarly, Schnabel (2016) reports that the more non-religious persons there are in a country, the greater material gender equality tends to be.

Data on economic growth, government size and fertility rates are taken from the WDI database. Information on irreligiosity and restrictions on rights and liberties are taken from the Pew Global Religious Landscape report and Freedom in the World, respectively. Economic growth is measured as the percentage change in real GDP per capita, and government size is proxied by the ratio of government consumption to GDP. The fertility rate is the number of births per woman, and I use the share of a country's religiously unaffiliated population as a proxy for irreligiosity. Restrictions on rights and liberties are calculated as the sum of the Freedom in the World political rights \& civil liberties country ratings, where higher scores indicate fewer freedoms. Table 1 provides some descriptive statistics for the variables under study.

\section{Method}

An important step when using panel data models involves choosing between the fixed effects and random effects estimator. Under the random-effects approach, the country-specific effects would be assumed to be random and uncorrelated with the regressors, which is rarely satisfied in practice. The fixed effects approach allows for any arbitrary correlation between 
country-specific effects and the independent variables. I employ the Hausman test to choose between the alternative estimators. The test rejects the null that random effects are fully efficient $\left(\chi^{2}=58.12\right.$, $p$-value $\left.<0.001\right)$, suggesting that the fixed effects model is preferred. However, there are two shortcomings of using the fixed approach in this study. First, the within transformation in the fixed effects regression wipes anything that is time-invariant. As such, one cannot estimate the coefficients on the time-invariant variables, such as the irreligiosity variable used in this study. Second, the literature suggests that two of the control variables (economic growth and fertility) are likely to be endogenous (Cuberes \& Teignier, 2014; Neyer et al., 2013; Seguino, 2000; Mason, 1987). Failure to account for endogeneity raises concerns about simultaneity bias. Against this backdrop, I opt to use the HausmanTaylor panel estimation technique to investigate the impact of tourism on gender equality. The Hausman-Taylor approach has the advantages of both the fixed effects and random effects estimators. It is an instrumental variable estimator that addresses the issue of correlation between the independent variables and the unobserved country-specific effects and also allows the coefficients of time-invariant regressors to be estimated (Hausman \& Taylor, 1981).

The following model is thus estimated:

$$
\text { Equality }_{i t}=\alpha_{0}+\alpha_{1} \text { Tourism }_{i t}+\alpha_{2} X_{i t}+\alpha_{3} W_{i t}+\alpha_{4} Y_{i}+u_{i}+\epsilon_{i t}
$$

where $i$ is the countries and $t$ denotes the year under concern. Equality represents gender inequality in the labour market and Tourism is the tourism intensity variable. $X, W$ and $Y$ represent subsets of the control variables. $X$ contains the time-varying variables exogenous variables (government size and restrictions on rights and liberties and irreligiosity), $W$ represents the time-varying endogenous variables (economic growth and the fertility rate) and $Y$ includes the time-invariant exogenous variable, irreligiosity.

\section{Results}

Bi-variate correlations

Table 2 presents the pairwise correlations between the gender equality measures and tourism. As noted previously, the gender gap in economic participation and opportunity variable is an amalgamation of five gender gap indicators. As would be expected, there are positive and significant correlations between the sub-components and the composite measure of gender inequality (evidenced by correlation coefficients ranging from 0.32 to 0.82 ). However, the correlations between the subcomponents of gender gaps in the economic participation and opportunity index vary, ranging from weak negative correlations to moderate positive relationships. The lack of a strong correlation between the subcomponents suggests that the individual indicators exhibit some degree of independent behaviour. It is thus possible that tourism's impact may vary across the labour market indicators. Accordingly, the empirical analyses are carried out on the composite and individual components of the gender equality in economic participation and opportunity variable.

Concerning the relationship between tourism and gender equality in the labour market, there is some evidence of a positive relationship between tourism and most of the gender equality measures. The strongest correlation can be found in the equality in advancement variables, which range from 0.24 to 0.32 . Gaps in the labour force participation rate are hardly associated with tourism, evidenced by a correlation coefficient of 0.04 . In contrast, the correlation coefficient for tourism and gender equality in wages is negative and statistically 
insignificant ( $p$-value $=0.31$ ). These findings are illustrated in Figure 1, which plots average gender equality against average tourism intensity over the sample period.

\section{Hausmann-Taylor estimates}

Thus far, the analysis suggests that tourism countries with a higher degree of tourism specialisation may experience small gender gaps in some aspects of the labour market. However, several other variables influence gender equality outside of tourism, and the exclusion of these variables could be masking the underlying relationship between the variables. Table 2 presents the panel regressions, inclusive of the various controls. The first column presents the results for the impact of tourism on gender gaps in areas of employment (the composite index) and columns two to six present tourism's impact on the five subindicators.

The results suggest that for the full sample, there is a positive relationship between tourism and the composite gender equality index. Specifically, the coefficient suggests that a 1 logpoint increases in tourism intensity is associated with a 0.01-point increase in the economic participation and opportunity index on average. A look at the subcomponents suggests that the link between gender equality in the labour market and tourism seems to be driven by the relationship between tourism and gender equality in career advancement. Greater tourism specialisation is associated with smaller gaps between the ratio of women to men among legislators, senior officials and managers. However, there is no evidence of a statistically significant relationship between tourism intensity and gender gaps in labour force participation, remuneration or technical and professional workers - at least at the conventional levels of testing.

Turning now to the control variables, Table 2 suggests that along with tourism density, crosscountry differences in the economic participation and opportunity index can be explained by differences in the fertility rates and government size across countries. The results indicate that higher fertility rates are negatively associated with gender equality and that there is a positive relationship between government size and gender equality. Contrary to a-priori expectations, growth, irreligiosity and restrictions on rights and liberties do not have a statistically significant impact on the composite index capturing gender gaps in economic participation and opportunity. Like the tourism variable, the impact of the control variables varies across the subcomponents of the economic participation and opportunity index. For example, growth is inversely related to gender parity in the female to male ratio among technical and professional workers, is positively associated with perceptions of wage equality for similar work but is unrelated to gender gaps in senior roles and the earned income. Fertility rates are negatively associated with gender equality in labour force participation, professional and technical roles and wages for similar work. Government size is only (positively) related to the equality in career advancement subcomponents. Meanwhile, irreligiosity only promotes gender equality in labour force participation and professional and technical roles. The variation in the determinants of the subcomponents is not surprising. As alluded to earlier, the subcomponents of the index were weakly correlated, implying that the individual indicators exhibit some degree of independent behaviour and by extension, differences in their determinants.

\section{Heterogeneity in relationship between tourism gender inequality}

As alluded to previously, women's participation in the tourism sector is dictated by institutional and socio-cultural gender norms, which vary across countries. It is plausible then that tourism's impact on gender equality may not be homogeneous. In this subsection, I 
evaluate whether the link between tourism and gender equality varies across subsets of countries. To carry out this task, I re-estimated the panel regressions using sub-samples of countries based on their level of development and regional classification. The countries are first divided into two groups: developed economies and emerging and developing economies. The emerging and developing economies are then grouped by geographical regions: (1) East Asia and the Pacific; (2) Europe and Central Asia; (3) Latin America and the Caribbean; (4) Middle East and North Africa; (5) South Asia and (6) Sub-Saharan Africa. The estimated impact of tourism on gender equality for these seven country groupings (after controlling for the impact of other variables) is shown in Table $3^{1}$.

Tourism is positively related to the composite gender equality index in three country groupings: East Asia and the Pacific, Europe and Central Asia and the developed countries. However, there is no evidence of a statistically significant relationship between tourism and the overall gender equality in the labour market for countries in Latin America and the Caribbean; the Middle East and Northern Africa; and South Asia. For Sub-Saharan Africa, the coefficient on the tourism variable is negative and statistically significant, hinting that tourism may act as a hindrance to gender equality in this region.

An analysis of the subcomponents lends further credence to the notion that the effects of tourism on gender equality vary across regions. To recap, in the regression using the full sample, the only subcomponent that appeared to be affected by tourism is the measure capturing gender parity in senior roles. The only region whose results are in line with those observed for the full sample of countries is Europe and Central Asia: tourism only has a significant impact on equality in senior roles, and the impact is positive. For East Asia and the Pacific region, tourism is only statistically related to gender equality in the earned income subcomponent, where an increase in tourism intensity serves to reduce the gender gap in earned income. The South Asian and Latin American and Caribbean regions present interesting case studies. While there is no evidence of a relationship between tourism and the overall gender equality index in these two regions, the results suggest that tourism has an impact on some of the subcomponents of the index. For Latin America and the Caribbean, an increase in tourism intensity is a deterrent to gender inequality in professional and technical roles. However, it promotes equality in senior roles and equality in earned income. Turning to the case of South Asian countries, tourism has a positive effect on equality in labour force participation and a negative effect on equality in earned income. For these two regions, the positive and negative tourism effects on the subindices may cancel each other out, resulting in the observed statistically insignificant association between tourism and the composite gender parity index.

With respect to Sub-Saharan Africa, the results suggest that the observed negative relationship between tourism and the composite measure of gender equality may be stemming from tourism's impact on the gender advancement gap. Specifically, the coefficient on the tourism variable in both the equality in senior roles and the equality in professional and technical roles is negative and statistically significant. Meanwhile, for countries in the Middle East and North Africa, tourism is neither a blessing nor a curse. This is the only region where there is no evidence of a statistically significant association between tourism and gender equality in neither aggregate or disaggregate form.

\footnotetext{
${ }^{1}$ The impact of the control variables is not reported in Table 3 to save space. However, results for the full specifications are available from the authors on request.
} 
The final group is the developed countries. The results suggest that the benefits of tourism are greatest for this group. In this subset of countries, an increase in tourism intensity has a positive (and significant) impact on three of the five components of the gender equality index, specifically, gender equality in labour force participation, senior roles and earned income.

The analysis thus far highlighted the heterogenous impact of tourism on gender equality in the labour market across subsamples of countries. A point hitherto unexplored concerns the areas in which the impact of tourism is consistent across the board. There is only one consistent result: irrespective of the sample used, there is no evidence of a significant relationship between tourism and gender equality in wages for similar work.

\section{Concluding remarks}

The UNTWO and UNDP have presented tourism as a tool to advance the universal 2030 Agenda for Sustainable Development (UNWTO \& UNDP, 2017). One of the most important items on this agenda is achieving gender equality and empowering all women and girls. Gender equality and women's empowerment is listed as integral for progress across all sustainable development goals (United Nations, 2015). However, it is not clear whether tourism has contributed to gender equality, particularly in gender equality in the labour market. The literature to date suggests that tourism generates both opportunities and barriers to women's economic empowerment, and by extension, gender equality in the labour market.

In this study, I investigate the effect of tourism on gender equality in the labour market. The paper provides solid evidence that tourism is a mixed blessing. The results suggest that tourism's impact on gender equality is not monolithic but varies with the labour market indicator and context under study. Evidence of a positive correlation between tourism and gender equality was greatest for developed countries. In this group of countries, increases in tourism intensity is associated with greater equality in labour force participation, senior roles and equality in earned income. My results suggest that in the developing world, tourism's effects vary across regions. I find that for developing countries in Europe and Central Asia, tourism is statistically related to equality in senior roles (positive impact), and in East Asia and the Pacific, tourism promotes income equality. In regions like South Asia and Latin America and the Caribbean, there is evidence of negative and positive effects on gender gaps in labour markets, while in the Middle East and Northern Africa, there is no evidence to suggest that tourism influences gender equality in the labour market. Finally, tourism had the greatest negative impact on Sub-Saharan Africa. Here, tourism appears to reinforce gender inequalities though its negative impacts on career progression.

The observed heterogeneity in the impact of tourism is not surprising. Even though tourism has to the potential to empower women, tourism employment does not operate in isolation to the destination's labour market. A consensus in the literature is that social, cultural and institutionalised norms have a considerable influence on gender relations and by extension, women's employment across nations (Akerlof \& Kranton, 2000; World Economic Forum, 2020). Tourism's ability to facilitate female economic empowerment and promote gender equality is thus largely contingent on how deeply gendered norms are embedded in a destination's social, political and legal landscape (Mooney, 2018). In other words, the nature of a society (particularly gendered power relations and gender-role ideologies) significantly affects the impact that tourism specialisation can have on gender equality. Within the context of the study, the finding that tourism's benefits to gender equality is greatest in developed 
countries is in line findings that in developed countries, there are less barriers to gender equality, such as discriminatory laws, practices, attitudes and gender stereotypes (Bergh, 2007; Inglehart \& Welzel, 2005; World Bank, 2020).

Taken together, the quantitative evidence presented in this study suggests that tourism's ability to bolster gender equality is a complex issue. One way to exponentiate the positive impact of tourism is to promote gender sensitive work decent work conditions in tourism. As alluded to earlier, tourism work is often precarious and characterised by low pay, weak protections, and exploitative working conditions (Bianchi \& de Man, 2021). The absence of decent work conditions in tourism in various states, coupled with the observed feminisation of tourism, could serve to exacerbate gender inequality. As a starting point for promoting decent work in tourism, policy makers could design and mandate the use of Human Rights Impact Assessments in tourism, specifically ones focused on the right to decent work. Moreno and Cole (2019) note that "Human Rights Impact Assessments are an essential tool for businesses to conduct due diligence to comply with the UN Guiding Principles and understand their impact on their stakeholders". There is also a need for the use of tools to evaluate, monitor and address the horizontal and vertical segregation in tourism and promote gender sensitive decent work in tourism. An example of such tools are gender audits (Moreno $\&$ Cole, 2019), which can be used to identify critical gaps and challenges and address gender biases.

At this juncture, it is important to note that while policy interventions in tourism can help bolster tourism's impact on gender equality, a key challenge would be implementing these policies in countries with system-wide gender challenges. Under such regimes, it is unlikely that there will be widespread buy-in to gender transformative policies. Thus, promoting a gender sensitive workforce in tourism would also require policies targeted at overcoming patriarchy. Policymakers must look at their labour market dynamics to craft appropriate and effective tourism national policies, strategies and action plans to reduce tourism's adverse effects and ensure that men and women equally benefit from tourism. Ferguson (2011) suggests that policymakers and practitioners carry out substantial research on gender issues and female empowerment within the country in order to maximise the impact of any proposed programmes and projects that will utilise tourism to contribute to gender equality and empower women. Once the context is fully understood, tourism policy makers and practitioners can work alongside the private sector and other tourism stakeholders to design targeted interventions to promote decent work for women in tourism.

\section{References}

Aghazamani, Y., \& Hunt, C. A. (2017). Empowerment in tourism: A review of peer-reviewed literature. Tourism Review International, 21(4), 333-346.

Akerlof, G. A., \& Kranton, R. E. (2000). Economics and identity. The Quarterly Journal of Economics, 115(3), 715-753.

Anyanwu, J. C., \& Augustine, D. (2013). Gender equality in employment in Africa: Empirical analysis and policy implications. African Development Review, 25(4), 400-420.

Baum, T. (2013). International Perspectives on Women and Work in Hotels, Catering and Tourism (No. 1/2013; Bureau for Gender Equality Working Paper Series). International Labour Organization. 
Baum, T., Cheung, C., Kong, H., Kralj, A., Mooney, S., Ramachandran, S., Dropulić Ružić, M., \& Siow, M. L. (2016). Sustainability and the tourism and hospitality workforce: A thematic analysis. Sustainability, 8(8), 809.

Bergh, J. (2007). Gender attitudes and modernization processes. International Journal of Public Opinion Research, 19(1), 5-23.

Bianchi, R. V., \& de Man, F. (2021). Tourism, inclusive growth and decent work: A political economy critique. Journal of Sustainable Tourism, 29(2-3), 353-371.

Blau, F. D., \& Kahn, L. M. (2017). The gender wage gap: Extent, trends, and explanations. Journal of Economic Literature, 55(3), 789-865.

Brandt, D. (2018). Wage determinants in the Swedish tourism sector. Scandinavian Journal of Hospitality and Tourism, 18(1), 18-38.

Buttrose, I., \& Adams, P. (2005). Mother Guilt: Australian Women Reveal Their True Feelings about Motherhood. Viking: Penguin Group.

Bynoe, R., \& Jackman, M. (2019). Gender Analysis of Selected Public Programmes and Services in Barbados.

Carvalho, I., Costa, C., Lykke, N., \& Torres, A. (2019). Beyond the glass ceiling: Gendering tourism management. Annals of Tourism Research, 75, 79-91.

Casado-Díaz, J. M., \& Simon, H. (2016). Wage differences in the hospitality sector. Tourism Management, 52, 96-109.

Cuberes, D., Priyanka, S., \& Teignier, M. (2019). The determinants of entrepreneurship gender gaps: A cross-country analysis. Review of Development Economics, 23(1), 72101.

Cuberes, D., \& Teignier, M. (2014). Gender inequality and economic growth: A critical review. Journal of International Development, 26(2), 260-276.

Deere, C. D., \& León, M. (2003). The gender asset gap: Land in Latin America. World Development, 31(6), 925-947.

Ferguson, L. (2011). Promoting gender equality and empowering women? Tourism and the third Millennium Development Goal. Current Issues in Tourism, 14(3), 235-249.

Figueroa-Domecq, C., Palomo, J., Flecha, M. D., Segovia-Perez, M., \& Vico, A. (2017). Is the tourism and gender research area igniting: A bibliometric analysis. Revista Turismo \& Desenvolvimento, 27(28), 173-175.

Figueroa-Domecq, C., Pritchard, A., Segovia-Pérez, M., Morgan, N., \& Villacé-Molinero, T. (2015). Tourism gender research: A critical accounting. Annals of Tourism Research, 52, 87-103.

Genç, R. (2018). The Impact of Tourism in the Reduction of Gender Inequality. Trakya Üniversitesi iktisadi ve Idari Bilimler Fakültesi Dergisi, 7(1), 20-35.

Gil Arroyo, C., Barbieri, C., Sotomayor, S., \& Knollenberg, W. (2019). Cultivating Women's Empowerment through Agritourism: Evidence from Andean Communities. Sustainability, 11(11), 3058.

Gouda, M., \& Potrafke, N. (2016). Gender equality in muslim-majority countries. Economic Systems, 40(4), 683-698.

Guimarães, C. R. F. F., \& Silva, J. R. (2016). Pay gap by gender in the tourism industry of Brazil. Tourism Management, 52, 440-450.

Hausman, J. A., \& Taylor, W. E. (1981). Panel data and unobservable individual effects. Econometrica: Journal of the Econometric Society, 1377-1398. 
Hutchings, K., Moyle, C., Chai, A., Garofano, N., \& Moore, S. (2020). Segregation of women in tourism employment in the APEC region. Tourism Management Perspectives, 34 , 100655.

Inglehart, R., \& Welzel, C. (2005). Modernization, cultural change, and democracy: The human development sequence. Cambridge University Press.

International Finance Corporation. (2017). Women and Tourism: Designing for Inclusion (Tourism for Development Knowledge Series). World Bank Group.

International Labour Office. (2017). ILO guidelines on decent work and socially responsible tourism. International Labour Office, Sectoral Policies Department.

International Labour Organization. (2016). Women at work: Trends 2016. International Labour Office. https://www.ilo.org/wcmsp5/groups/public/---dgreports/---dcomm/--publ/documents/publication/wcms_457317.pdf

International Labour Organization. (2018). Care work and care jobs for the future of decent work. International Labour Office.

Jackman, M. (2014). Output volatility and tourism specialization in small island developing states. Tourism Economics, 20(3), 527-544.

Jackman, M., \& Lorde, K. (2021). Gender gaps in (paid) work hours of heads of households: Empirical evidence from Barbados. International Journal of Manpower.

Jackman, M., Lorde, T., Lowe, S., \& Alleyne, A. (2011). Evaluating tourism competitiveness of small island developing states: A revealed comparative advantage approach. Anatolia, 22(3), 350-360.

Kieran, C., Sproule, K., Doss, C., Quisumbing, A., \& Kim, S. M. (2015). Examining gender inequalities in land rights indicators in Asia. Agricultural Economics, 46(S1), 119-138.

Klingorová, K., \& Havlíček, T. (2015). Religion and gender inequality: The status of women in the societies of world religions. Moravian Geographical Reports, 23(2), 2-11.

Kolovich, L. (Ed.). (2018). Fiscal policies and gender equality. International Monetary Fund.

Kortt, M. A., Sinnewe, E., \& Pervan, S. J. (2018). The gender wage gap in the tourism industry: Evidence from Australia. Tourism Analysis, 23(1), 137-149.

Lillo-Bañuls, A., \& Casado-Díaz, J. M. (2015). Exploring the relationship between educational mismatch, earnings and job satisfaction in the tourism industry. Current Issues in Tourism, 18(4), 361-375.

Maceira, H. M. (2017). Economic benefits of gender equality in the EU. Intereconomics, $52(3), 178-183$.

Mason, K. O. (1987). The impact of women's social position on fertility in developing countries. Sociological Forum, 2(4), 718-745.

Maume, D. (1999). Occupational segregation and the career mobility of white men and women. Social Forces, 77(4), 1433-1459.

Meara, K., Pastore, F., \& Webster, A. (2020). The gender pay gap in the USA: A matching study. Journal of Population Economics, 33(1), 271-305.

Mooney, S. (2018). Jobs for the girls? Women's employment and career progression in the hospitality industry. In R. Burke \& J. Hughes (Eds.), Handbook of Human Resource Management in the Tourism and Hospitality Industries (pp. 184-215). Edward Elgar Publishing.

Moreno, D., \& Cañada, E. (2018). Gender dimensions in tourism work (No. 4; Informes En Contraste Series). Alba Sud Publishing.

Moreno, D., \& Cole, S. (2019). No sustainability for tourism without gender equality. Journal of Sustainable Tourism. 
Morgan, N., \& Pritchard, A. (2019). Gender Matters in Hospitality (invited paper for 'luminaries' special issue of International Journal of Hospitality Management). International Journal of Hospitality Management, 76, 38-44.

Morsy, H. (2020). Access to finance-mind the gender gap. The Quarterly Review of Economics and Finance.

Moswete, N., \& Lacey, G. (2015). "Women cannot lead": Empowering women through cultural tourism in Botswana. Journal of Sustainable Tourism, 23(4), 600-617.

Movono, A., \& Dahles, H. (2017). Female empowerment and tourism: A focus on businesses in a Fijian village. Asia Pacific Journal of Tourism Research, 22(6), 681-692.

Muñoz-Bullón, F. (2009). The gap between male and female pay in the Spanish tourism industry. Tourism Management, 30(5), 638-649.

Nassani, A. A., Aldakhil, A. M., Abro, M. M. Q., Islam, T., \& Zaman, K. (2019). The impact of tourism and finance on women empowerment. Journal of Policy Modeling, 41(2), 234-254.

Neyer, G., Lappegåard, T., \& Vignoli, D. (2013). Gender equality and fertility: Which equality matters? European Journal of Population/Revue Européenne de Démographie, 29(3), 245-272.

Oliver, X., \& Sard, M. (2020). Gender Wage Gap in Hospitality. Journal of Hospitality \& Tourism Research, 1096348020909423.

Pastore, F., Webster, A., \& Hope, K. (2020). Assessing the role of women in tourism related sectors in the Caribbean. International Journal of Tourism Research.

Peña-Sánchez, A. R., Ruiz-Chico, J., Jiménez-García, M., \& López-Sánchez, J. A. (2020). Tourism and the SDGs: An Analysis of Economic Growth, Decent Employment, and Gender Equality in the European Union (2009-2018). Sustainability, 12(13), 5480.

Pritchard, A. (2014). Gender and feminist perspectives in tourism research. The Wiley Blackwell Companion to Tourism, 314-324.

Ramchurjee, N. (2011). "Tourism" a Vehicle for Women's Empowerment: Prospect and Challenges.

https://www.researchgate.net/profile/Nichola_Ramchurjee/publication/256505214 _Tourism_a_Vehicle_for_Women's_Empowerment_Prospect_and_Challenges/links/ 5a04ce5c0f7e9bc4078f6601/Tourism-a-Vehicle-for-Womens-EmpowermentProspect-and-Challenges.pdf

Ribeiro, L. C. D. S., Lopes, T. H. C. R., Montenegro, R. L. G., \& Andrade, J. R. D. L. (2018). Employment dynamics in the Brazilian tourism sector (2006-2015). Tourism Economics, 24(4), 418-433.

Rinaldi, A., \& Salerno, I. (2019). The tourism gender gap and its potential impact on the development of the emerging countries. Quality \& Quantity, 1-13.

Santero-Sanchez, R., Segovia-Pérez, M., Castro-Nuñez, B., Figueroa-Domecq, C., \& TalónBallestero, P. (2015). Gender differences in the hospitality industry: A job quality index. Tourism Management, 51, 234-246.

Schnabel, L. (2016). Religion and gender equality worldwide: A country-level analysis. Social Indicators Research, 129(2), 893-907.

Seguino, S. (2000). Gender inequality and economic growth: A cross-country analysis. World Development, 28(7), 1211-1230.

Seguino, S. (2011). Help or hindrance? Religion's impact on gender inequality in attitudes and outcomes. World Development, 39(8), 1308-1321. 
Seguino, S. (2016). Global trends in gender equality. Journal of African Development, 18(1), 9-30.

Silva, J. R., \& Guimarães, C. R. F. F. (2017). Wage differentials in Brazil: Tourism vs. other service sectors. Cogent Economics \& Finance, 5(1), 1319606.

Sinclair, M. T. (1997). Issues and theories of gender and work in tourism. In Gender, Work and Tourism (pp. 1-14). Routledge.

Soria, J. A. C., \& Teigeiro, L. R. (2019). The employment multiplier in the European hospitality industry: A gender approach. International Journal of Contemporary Hospitality Management.

Stritch, J. M., \& Villadsen, A. R. (2018). The gender wage gap and the moderating effect of education in public and private sector employment. Public Administration, 96(4), 690-706.

Uduji, J. I., Okolo-Obasi, E. N., \& Asongu, S. A. (2020). Sustaining cultural tourism through higher female participation in Nigeria: The role of corporate social responsibility in oil host communities. International Journal of Tourism Research, 22(1), 120-143.

United Nations. (2015). Transforming our world: The 2030 agenda for sustainable development. (A/RES/70/1). United Nations. https://sustainabledevelopment.un.org/content/documents/21252030\%20Agenda\% 20for\%20Sustainable\%20Development\%20web.pdf

United Nations Development Programme. (2015). "Technical Notes" in Human Development Report. United Nations Development Programme.

UNWTO. (2019). Global report on women in tourism (2nd ed.). UNWTO.

UNWTO, \& UNDP. (2017). Tourism and the Sustainable Development Goals-Journey to 2030. UNWTO.

Wamboye, E. F., \& Seguino, S. (2015). Gender effects of trade openness in sub-Saharan Africa. Feminist Economics, 21(3), 82-113.

Weeden, K. A., Cha, Y., \& Bucca, M. (2016). Long work hours, part-time work, and trends in the gender gap in pay, the motherhood wage penalty, and the fatherhood wage premium. RSF: The Russell Sage Foundation Journal of the Social Sciences, 2(4), 71102.

Winchenbach, A., Hanna, P., \& Miller, G. (2019). Rethinking decent work: The value of dignity in tourism employment. Journal of Sustainable Tourism, 27(7), 1026-1043.

World Bank. (2012). World Development Report 2012: Gender Equality and Development (World Development Report). World Bank.

World Bank. (2020). Women, Business and the Law 2020 (Women, Business and the Law). World Bank.

World Economic Forum. (2020). The global gender gap report 2020. World Economic Forum.

WTTC. (2020). Travel \& Tourism Global Economic Impact and Trends Report 2020 (Economic Impact Reports). World Travel and Tourism Council.

Zhang, J., \& Zhang, Y. (2020). Tourism and gender equality: An Asian perspective. Annals of Tourism Research, 85, 103067. 
Table 1: Descriptive Statistics (Based on estimation sample)

\begin{tabular}{|c|c|c|c|c|c|}
\hline Variable & Data source & Mean & $\begin{array}{l}\text { Standard } \\
\text { deviation }\end{array}$ & Min & Max \\
\hline Equality in participation and opportunity & World Economic Forum Gender Gap Reports & 0.64 & 0.12 & 0.23 & 0.91 \\
\hline Equality in labour force participation & World Economic Forum Gender Gap Reports & 0.74 & 0.18 & 0.21 & 1.00 \\
\hline Equality in professional and technical roles & World Economic Forum Gender Gap Reports & 0.84 & 0.23 & 0.06 & 1.00 \\
\hline Equality in senior roles & World Economic Forum Gender Gap Reports & 0.43 & 0.23 & 0.02 & 1.00 \\
\hline Wage equality for similar work & World Economic Forum Gender Gap Reports & 0.66 & 0.09 & 0.39 & 0.90 \\
\hline Equality in earned income & World Economic Forum Gender Gap Reports & 0.57 & 0.16 & 0.15 & 1.00 \\
\hline Tourism intensity (logged) & World Bank Development Indicators & -1.51 & 1.66 & -7.12 & 2.27 \\
\hline Growth $(\%)$ & World Bank Development Indicators & 2.17 & 3.72 & -18.80 & 24.05 \\
\hline Fertility rate & World Bank Development Indicators & 2.61 & 1.31 & 1.05 & 6.99 \\
\hline Government size (\%) & World Bank Development Indicators & 16.16 & 5.24 & 2.05 & 39.88 \\
\hline Restrictions on rights and liberties & Freedom House Global Freedom Scores & 6.06 & 3.66 & 2.00 & 14.00 \\
\hline Irreligiosity $(\%)$ & Pew Research Center Global Religious Landscape & 10.21 & 14.05 & 0.10 & 76.40 \\
\hline
\end{tabular}


Table 3: Pairwise Correlation - Gender inequality in the labour market indices and tourism

\begin{tabular}{|c|c|c|c|c|c|c|c|}
\hline & \multirow[b]{3}{*}{$\begin{array}{l}\text { Equality in participation } \\
\text { and opportunity }\end{array}$} & \multicolumn{5}{|c|}{ Sub-components of index } & \multirow{3}{*}{ Tourism } \\
\hline & & \multirow[b]{2}{*}{$\begin{array}{l}\text { Equality in } \\
\text { labour force } \\
\text { participation }\end{array}$} & \multicolumn{2}{|c|}{ Equality in advancement } & \multicolumn{2}{|c|}{ Equality in renumeration } & \\
\hline & & & $\begin{array}{l}\text { Equality in } \\
\text { professional and } \\
\text { technical roles }\end{array}$ & $\begin{array}{l}\text { Equality } \\
\text { in } \\
\text { senior roles }\end{array}$ & $\begin{array}{l}\text { Equality in } \\
\text { earned } \\
\text { income }\end{array}$ & $\begin{array}{l}\text { Wage equality } \\
\text { for similar } \\
\text { work }\end{array}$ & \\
\hline $\begin{array}{l}\text { Equality in participation } \\
\text { and opportunity }\end{array}$ & 1.00 & & & & & & \\
\hline $\begin{array}{l}\text { Equality in labour force } \\
\text { participation }\end{array}$ & $0.82^{* * *}$ & 1.00 & & & & & \\
\hline $\begin{array}{l}\text { Equality in professional and } \\
\text { technical roles }\end{array}$ & $0.68^{* * *}$ & $0.52^{* * *}$ & 1.00 & & & & \\
\hline $\begin{array}{l}\text { Equality in } \\
\text { senior roles }\end{array}$ & $0.65^{* * *}$ & $0.40^{* * *}$ & $0.53^{* * *}$ & 1.00 & & & \\
\hline Equality in earned income & $0.81^{* * *}$ & $0.80^{* * *}$ & $0.41^{* * *}$ & $0.37^{* * *}$ & 1.00 & & \\
\hline $\begin{array}{l}\text { Wage equality for similar } \\
\text { work }\end{array}$ & $0.32^{* * *}$ & $0.10^{* * *}$ & $-0.08^{* *}$ & $-0.05^{+}$ & $0.18^{* * *}$ & 1.00 & \\
\hline Tourism & $0.18^{* * *}$ & $0.04^{*}$ & $0.32^{* * *}$ & $0.24^{* * *}$ & $0.12^{* * *}$ & -0.03 & 1.00 \\
\hline
\end{tabular}


Table 3: Panel regression results (Hausmann-Taylor approach)

\begin{tabular}{|c|c|c|c|c|c|c|}
\hline & \multirow{3}{*}{$\begin{array}{l}\text { Equality in } \\
\text { participation and } \\
\text { opportunity }\end{array}$} & \multicolumn{5}{|c|}{ Sub-components } \\
\hline & & \multirow[b]{2}{*}{$\begin{array}{l}\text { Equality in labour } \\
\text { force participation }\end{array}$} & \multicolumn{2}{|c|}{ Equality in advancement } & \multicolumn{2}{|c|}{ Equality in renumeration } \\
\hline & & & $\begin{array}{l}\text { Equality in } \\
\text { professional and } \\
\text { technical roles }\end{array}$ & $\begin{array}{l}\text { Equality in } \\
\text { senior roles }\end{array}$ & $\begin{array}{l}\text { Equality in } \\
\text { earned } \\
\text { income }\end{array}$ & $\begin{array}{c}\text { Wage equality } \\
\text { for similar } \\
\text { work }\end{array}$ \\
\hline \multirow{2}{*}{ Tourism Intensity } & $0.01^{+}$ & 0.00 & 0.00 & $0.03^{*}$ & 0.00 & 0.00 \\
\hline & $(0.01)$ & $(0.01)$ & $(0.01)$ & $(0.02)$ & $(0.01)$ & $(0.01)$ \\
\hline \multirow{2}{*}{ Growth } & 0.04 & -0.05 & $-0.12^{+}$ & -0.12 & 0.09 & $0.09^{*}$ \\
\hline & $(0.04)$ & $(0.04)$ & $(0.07)$ & $(0.08)$ & $(0.08)$ & $(0.04)$ \\
\hline \multirow[t]{2}{*}{ Fertility rate } & $-0.04^{* *}$ & $-0.04^{+}$ & $-0.11^{* * *}$ & -0.04 & -0.04 & $-0.03^{*}$ \\
\hline & $(0.01)$ & $(0.02)$ & $(0.03)$ & $(0.04)$ & $(0.02)$ & $(0.01)$ \\
\hline \multirow{2}{*}{ Government size } & $0.22^{+}$ & 0.19 & $0.71^{* *}$ & $0.60^{*}$ & $0.43^{* *}$ & 0.12 \\
\hline & $(0.12)$ & $(0.18)$ & $(0.23)$ & $(0.27)$ & $(0.16)$ & $(0.09)$ \\
\hline \multirow[t]{2}{*}{ Restrictions on rights and liberties } & 0.00 & -0.00 & -0.00 & 0.01 & 0.00 & 0.00 \\
\hline & $(0.00)$ & $(0.00)$ & $(0.01)$ & $(0.01)$ & $(0.00)$ & $(0.00)$ \\
\hline \multirow[t]{2}{*}{ Irreligiosity } & 0.02 & $0.21^{+}$ & $0.22^{+}$ & 0.09 & 0.12 & -0.00 \\
\hline & $(0.08)$ & $(0.11)$ & $(0.12)$ & $(0.19)$ & $(0.10)$ & $(0.05)$ \\
\hline \multirow[t]{2}{*}{ Constant } & $0.72^{* * *}$ & $0.80^{* * *}$ & $0.96^{* * *}$ & $0.42^{* *}$ & $0.58^{* * *}$ & $0.54^{* * *}$ \\
\hline & $(0.05)$ & $(0.07)$ & $(0.10)$ & $(0.15)$ & $(0.07)$ & $(0.04)$ \\
\hline No. of observations & 1,544 & 1,542 & 1,320 & 1,379 & 1,526 & 1,464 \\
\hline No. of countries & 143 & 143 & 132 & 135 & 143 & 140 \\
\hline
\end{tabular}

Notes: (1) Standard errors in in parentheses.

$(2)^{+} p<0.10,{ }^{*} p<0.05,{ }^{* *} p<0.01,{ }^{* * *} p<0.001$ 
Table 3: Panel regression estimates of the impact of tourism on gender equality in labour market by country groupings (HausmannTaylor approach)

\begin{tabular}{|c|c|c|c|c|c|c|}
\hline & \multirow{3}{*}{$\begin{array}{l}\text { Equality in } \\
\text { participation and } \\
\text { opportunity }\end{array}$} & \multicolumn{5}{|c|}{ Sub-components } \\
\hline & & \multirow[b]{2}{*}{$\begin{array}{l}\text { Equality in labour } \\
\text { force participation }\end{array}$} & \multicolumn{2}{|c|}{ Equality in advancement } & \multicolumn{2}{|c|}{ Equality in renumeration } \\
\hline & & & $\begin{array}{c}\text { Equality in } \\
\text { professional and } \\
\text { technical roles }\end{array}$ & $\begin{array}{l}\text { Equality in } \\
\text { senior roles }\end{array}$ & $\begin{array}{c}\text { Equality in } \\
\text { earned } \\
\text { income }\end{array}$ & $\begin{array}{c}\text { Wage equality } \\
\text { for similar } \\
\text { work } \\
\end{array}$ \\
\hline All countries & $\begin{array}{l}0.01^{+} \\
(0.01)\end{array}$ & $\begin{array}{c}0.00 \\
(0.01)\end{array}$ & $\begin{array}{c}0.00 \\
(0.01)\end{array}$ & $\begin{array}{l}0.03^{+} \\
(0.02)\end{array}$ & $\begin{array}{c}0.00 \\
(0.01)\end{array}$ & $\begin{array}{c}0.00 \\
(0.01)\end{array}$ \\
\hline \multicolumn{7}{|l|}{ Emerging and developing economies } \\
\hline Europe and Central Asia & $\begin{array}{c}0.01^{+} \\
(0.01)\end{array}$ & $\begin{array}{l}-0.00 \\
(0.01)\end{array}$ & $\begin{array}{c}0.01 \\
(0.01)\end{array}$ & $\begin{array}{l}0.08^{*} \\
(0.03)\end{array}$ & $\begin{array}{l}-0.01 \\
(0.01)\end{array}$ & $\begin{array}{l}-0.02 \\
(0.01)\end{array}$ \\
\hline East Asia and the Pacific & $\begin{array}{l}0.03^{+} \\
(0.02)\end{array}$ & $\begin{array}{c}0.02 \\
(0.02)\end{array}$ & $\begin{array}{c}0.07 \\
(0.06)\end{array}$ & $\begin{array}{c}0.08 \\
(0.05)\end{array}$ & $\begin{array}{l}0.08^{*} \\
(0.03)\end{array}$ & $\begin{array}{l}-0.08 \\
(0.06)\end{array}$ \\
\hline South Asia & $\begin{array}{l}-0.01 \\
(0.02)\end{array}$ & $\begin{array}{l}0.04^{*} \\
(0.02)\end{array}$ & $\begin{array}{c}0.02 \\
(0.04)\end{array}$ & $\begin{array}{c}0.01 \\
(0.03)\end{array}$ & $\begin{array}{c}-0.06^{* * *} \\
(0.01)\end{array}$ & $\begin{array}{l}-0.02 \\
(0.02)\end{array}$ \\
\hline Latin America and the Caribbean & $\begin{array}{c}0.02 \\
(0.02)\end{array}$ & $\begin{array}{c}0.04 \\
(0.03)\end{array}$ & $\begin{array}{l}-0.08^{*} \\
(0.04)\end{array}$ & $\begin{array}{l}0.06^{* *} \\
(0.02)\end{array}$ & $\begin{array}{c}0.04^{+} \\
(0.02)\end{array}$ & $\begin{array}{c}0.01 \\
(0.01)\end{array}$ \\
\hline Sub-Saharan Africa & $\begin{array}{l}-0.03^{*} \\
(0.01)\end{array}$ & $\begin{array}{c}0.00 \\
(0.02)\end{array}$ & $\begin{array}{l}-0.04^{*} \\
(0.02)\end{array}$ & $\begin{array}{l}-0.12^{+} \\
(0.06)\end{array}$ & $\begin{array}{l}-0.01 \\
(0.02)\end{array}$ & $\begin{array}{c}0.00 \\
(0.03)\end{array}$ \\
\hline Middle East and Northern Africa & $\begin{array}{c}0.02 \\
(0.01)\end{array}$ & $\begin{array}{l}-0.04 \\
(0.04)\end{array}$ & $\begin{array}{l}-0.03 \\
(0.03)\end{array}$ & $\begin{array}{l}-0.02 \\
(0.02)\end{array}$ & $\begin{array}{l}-0.02 \\
(0.04)\end{array}$ & $\begin{array}{c}0.02 \\
(0.02)\end{array}$ \\
\hline Developed economies & $\begin{array}{l}0.04^{* * *} \\
(0.01)\end{array}$ & $\begin{array}{l}0.07^{* * * *} \\
(0.01)\end{array}$ & $\begin{array}{c}0.00 \\
(0.03)\end{array}$ & $\begin{array}{l}0.06^{* *} \\
(0.02)\end{array}$ & $\begin{array}{l}0.05^{*} \\
(0.02)\end{array}$ & $\begin{array}{c}0.00 \\
(0.01)\end{array}$ \\
\hline Control Variables included? & Yes & Yes & Yes & Yes & Yes & Yes \\
\hline
\end{tabular}

Notes: (1) Standard errors in in parentheses.

$(2)^{+} p<0.10,{ }^{*} p<0.05,{ }^{* *} p<0.01,{ }^{* * *} p<0.001$ 
Figure 1: Average gender equality against average tourism intensity over the period 2006 to 2017

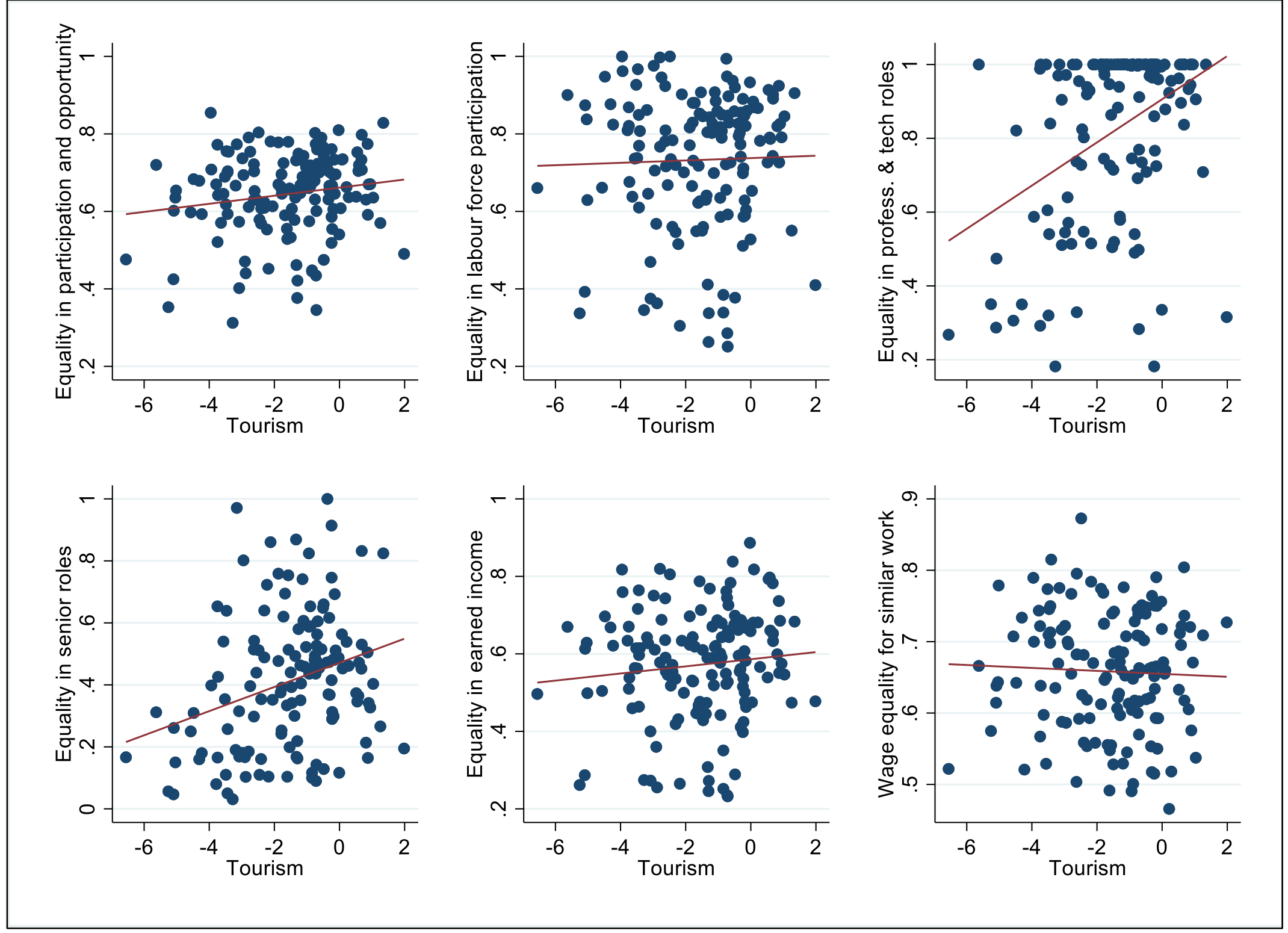


Appendix 1: Sample of countries

\begin{tabular}{|c|c|c|c|c|c|c|}
\hline \multirow[b]{2}{*}{ Developed economies } & \multicolumn{6}{|c|}{ Emerging and developing economies } \\
\hline & East Asia \& the Pacific & Europe \& Central Asia & $\begin{array}{l}\text { Latin America \& } \\
\text { the C'bean }\end{array}$ & $\begin{array}{l}\text { Middle East \& } \\
\text { North Africa }\end{array}$ & South Asia & Sub-Saharan Africa \\
\hline Australia & Brunei Darussalam & Albania & Argentina & Algeria & Bangladesh & Angola \\
\hline Austria & Cambodia & Armenia & Bahamas & Bahrain & Bhutan & Benin \\
\hline Belgium & China & Azerbaijan & Barbados & Egypt & India & Botswana \\
\hline Canada & Fiji & Belarus & Belize & Iran & Maldives & Burkina Faso \\
\hline Cyprus & Indonesia & Bosnia \& Herzegovina & Bolivia & Jordan & Nepal & Burundi \\
\hline Czech Republic & Lao PDR & Bulgaria & Brazil & Kuwait & Pakistan & Cameroon \\
\hline Denmark & Malaysia & Croatia & Cuba & Lebanon & Sri Lanka & Cape Verde \\
\hline Estonia & Mongolia & Georgia & Chile & Morocco & & Chad \\
\hline Finland & Philippines & Hungary & Colombia & Oman & & Ethiopia \\
\hline France & & Kazakhstan & Costa Rica & Qatar & & Gambia \\
\hline Germany & & Kyrgyzstan & Dominican Rep. & Saudi Arabia & & Ghana \\
\hline Greece & & Macedonia & Ecuador & Syria & & Guinea \\
\hline Iceland & & Moldova & El Salvador & Tunisia & & Kenya \\
\hline Ireland & & Montenegro & Guatemala & Yemen & & Lesotho \\
\hline Israel & & Poland & Guyana & & & Madagascar \\
\hline Italy & & Romania & Honduras & & & Malawi \\
\hline Japan & & Russian Federation & Jamaica & & & Mali \\
\hline Korea, Rep. & & Serbia & Mexico & & & Mauritius \\
\hline Latvia & & Tajikistan & Nicaragua & & & Mozambique \\
\hline Lithuania & & Turkey & Panama & & & Namibia \\
\hline Luxembourg & & Ukraine & Paraguay & & & Nigeria \\
\hline Malta & & Uzbekistan & Peru & & & Rwanda \\
\hline Netherlands & & & Suriname & & & Senegal \\
\hline New Zealand & & & Trinidad \& Tobago & & & South Africa \\
\hline Norway & & & Uruguay & & & Tanzania \\
\hline Portugal & & & Venezuela & & & Uganda \\
\hline Singapore & & & Argentina & & & Zambia \\
\hline Slovakia & & & & & & Zimbabwe \\
\hline Slovenia & & & & & & \\
\hline Spain & & & & & & \\
\hline Sweden & & & & & & \\
\hline Switzerland & & & & & & \\
\hline United Kingdom & & & & & & \\
\hline United States & & & & & & \\
\hline
\end{tabular}

